\title{
Structural Model Development: Branches, Attitudes and Self-Efficacy of Pedagogical Formation Program Pre-Service Teachers
}

\author{
Sadik Yuksel Sivaci ${ }^{1}$ \\ ${ }^{1}$ Curriculum and Instruction Division, Ahi Evran University, Kırşehir, Turkey \\ Correpondence: Sadik Yuksel Sivaci, Curriculum and Instruction Division, Ahi Evran University, Kırşehir, P.C.: \\ 40100, Turkey. E-mail: sysivaci@ahievran.edu.tr
}

Received: December 4, 2016

Accepted: December 25, 2016 Online Published: January 5, 2017

doi:10.5539/jel.v6n2p111

URL: http://dx.doi.org/10.5539/jel.v6n2p111

\begin{abstract}
In this study, the relationship between attitudes of pedagogical formation program pre-service teachers towards teaching profession and their self-efficacies has been examined. In this case, the effect of graduation branches of the pre-service teachers on teacher self-efficacies and the effect of teacher self-efficacies on attitudes towards teaching profession have been investigated. From this aspect, this research has the characteristics of causal-comparative research. Being suitable for the purpose of this research, it has been carried out with 300 pre-service teachers registered to pedagogical formation training certificate program at a state university in Turkey. Being conducted on pre-service teachers and established scaling models incidental to "Attitude Scale towards Teaching Profession" and "Teacher Self-Efficacy Scale" has been confirmed and the conformity index values obtained from the scaling model have shown good conformity. It is also seen that the structural equation model which is established in order to test the effect of branches on teacher self-efficacies and the effect of teacher self-efficacies on attitudes towards teaching profession has been confirmed and conformity index values have shown good conformity.
\end{abstract}

Keywords: branch, self-efficacy, attitude, pedagogical formation, teaching profession

\section{Introduction}

In recent years, a lot of studies have been done on attitude and self-efficacy levels of teachers which have important effects on the motivation and achievements of pre-service teachers. The more the efficacies of individuals increase, the more their performance and productivity will increase because of the effect on learning and teaching. On the other hand, increase of the success has an importance on being model not only by teaching in terms of cognition but also by the expression of teachers on the basis of emotion (Gökçe, 2000, pp. 21-26). These efficacies required by teaching profession show that a teacher can fulfill teaching by showing success both cognitively and emotionally-individually.

Bandura (1977), who is one of the pioneers of social learning theory asserting that self-efficacy affects behaviors of individuals positively, explain it by grounding on cognitive basics. In this regard, self-efficacy is described as individual's belief about being able to overcome a particular situation or a problem (pp. 191-192). Self-efficacy beliefs provide the foundation of human motivation, well-being and personal accomplishment because unless people believe that their actions can produce the outcomes they desire, they have little incentive to act or to persevere when they face obstacles (Erdem \& Demirel, 2007).

Efficacy beliefs increase if the teacher accepts that teaching performance, which makes contribution to the expectations that the teacher's next performances will be sufficient, is successful. In other respects, related to the expectations that the next performances will be unsuccessful, if the teacher accepts failure of the performance, their efficacy beliefs decrease. And consequently, differences between the teachers having high and low self-efficacy sense can occur. Keeping classroom management, giving feedback to the pre-service teachers and teaching lesson by using the latest methods affect the motivation and success of the pre-service teacher. In addition to this, instructors, who judge the ability of overcoming a complex information or skill which is essential to plan the explanations based on the pre-service teachers needs in a particular teaching context, will show more effort, continuity and tolerance in consequence of their stronger self-efficacy beliefs (Tschannen-Moran \& Woolfolk Hoy, 2006, pp. 945-946). 
"Teacher Self-Efficacy Scale" which has been developed by Tschannen-Moran and Woolfolk Hoy (2006) and adapted to Turkish by Çapa, Çakıroğlu and Sarıkaya and "Attitude Scale for Teaching Profession" which has been developed by Çetin are mostly used in the studies being done on self-efficacy and attitude.

Positive pre-service teacher attitudes and academic achievement increase are directly proportionate to teacher self-efficacy beliefs. Besides, as Milner and Woolfolk assert, planning and classroom practice are connected with the teacher self-efficacy beliefs and a teacher having a strong self-efficacy belief is better in these skills (2003, pp. 263-276).

In addition to teacher self-efficacy sense, as related to the qualifications of teachers, examination of teachers' attitude towards teaching profession creates another study field. In this context, attitude which is accepted as an important variance for the success in teaching profession is essential for obtaining intended efficiency. Attitude, described as a psychological variance such as behavioral, emotional and cognitive, requires being against or side with the attitude object (Anderson, 1988, pp. 421-426). In other words, attitude is a biased reaction directing behaviors shown by an individual towards any facts (Ülgen, 1995, p. 97).

Studies on attitude show that teachers, who do not have positive attitude towards teaching profession, have difficulty in achieving the goal and cannot obtain the intended efficiency. For the sake of example, Erden (1995, pp. 99-105) has carried his study on attitude towards teacher certification lessons and inferred that the individuals who have not given importance to these lessons have negative attitudes because they are not willing to be a teacher; on the contrary, the individuals who want to be a teacher are more inclined to develop positive attitude.

Baykara-Pehlivan has evaluated the relationship between the attitudes of individuals towards teaching profession and school in her study on pre-service class teachers. Baykara-Pehlivan finding out there is a significant relationship between these two concepts, has concluded that most of these pre-service teachers' attitudes towards their undergraduate programs affect the attitudes towards teaching profession (2004, pp. 211-218).

Within the scope of these similar researches, when we look at the studies being done with the pre-service teachers who have completed their formation programs, it has been argued whether there is an effect of this education in the case of attitude. In the study that he has searched for the attitudes of pre-service teachers getting formation education towards teaching profession, Sürücü (1997) defends that field knowledge, professional teaching knowledge and world knowledge should be taken into consideration in the nomination of teachers and that training teachers who have positive attitudes towards teaching profession should be given importance.

By looking at all those studies, it can be said that self-efficacy sense and attitude affect teachers as well as their pre-service teachers who take them as a model and who follow their behaviors in the case of obtaining desired efficiency. That is to say, that the teachers' attitudes towards teaching profession are positive and that their self-efficacy senses are high can be evaluated with the result of reaching the intended efficiency more easily.

Considering this fact; in this study, it is aimed to design a structural model revealing the relationship between pedagogical formation program pre-service teachers' graduated branches, their teacher self-efficacy senses and their attitudes towards teaching profession. In accordance with this purpose, scaling models have been established from the scales used in this research. Testing the verification progress of scaling models and reaching a general structural model have been tried.

\section{Method}

\subsection{Research Design}

In this research, the relationship between the attitudes towards teaching profession and self-efficacies of pedagogical formation program pre-service teachers has been examined. In this case, the effect of pre-service teachers' branches of graduation on teacher self-efficacies and the effect of teacher self-efficacies on their attitudes towards teaching profession have been searched. From this aspect, this research has the characteristics of casual-comparative research. Casual-comparative researches are the approaches that reveal the reasons of a substantial situation and the variables that affect these reasons (Fraenkel \& Wallen, 2006, p. 370).

\subsection{Study Group}

Being suitable for the purpose, distributions of pedagogical formation program pre-service teachers studying at a state university in Turkey in terms of the branch variables are given in Table 1. 
Table 1. Frequency and percentage distributions of pre-service teachers according to branch

\begin{tabular}{llll}
\hline Features & Categories & $f$ & $\%$ \\
\hline \multirow{4}{*}{ Branch } & Math & 53 & 17,7 \\
& Chemistry & 48 & 16,0 \\
& Geography & 48 & 16,0 \\
& Physics & 48 & 16,0 \\
& History & 46 & 15,3 \\
Total & Turkish Language and Literature & 57 & 19,0 \\
\hline
\end{tabular}

By looking at Table 1, when the distributions of pedagogical formation program pre-service teachers according to branches are examined, there are $53(17,7 \%)$ pre-service teachers graduated from Math, $48(16,0 \%)$ pre-service teachers graduated from Chemistry, $48(16,0 \%)$ pre-service teachers graduated from Geography, 48 $(16,0 \%)$ pre-service teachers graduated from Physics, $46(15,3 \%)$ pre-service teachers graduated from History, and $57(19,0 \%)$ pre-service teachers graduated from Turkish Language and Literature. In general, there are 300 $(100 \%)$ pre-service teachers attending this study.

\subsection{Data Collection Tools}

\section{Attitude Scale Towards Teaching Profession (ASTTP):}

With the purpose scale of determining pre-service teachers' attitudes towards teaching profession, "Attitude Scale towards Teaching Profession" developed by Çetin (2003) has been used. In this five point likert scale, there are 35 items that 15 of them negative and 20 of them positive. Three sub-factors have been developed and they are named as "Love" including 22 items, "Value" including 8 items, "Adaptation" including 5 items.

Teacher Self-Efficacy Scale (TSES):

In another scale, "Teacher Self-Efficacy Scale" prepared by Tschannen-Moran and Hoy has been used. The Turkish adaptation of this scale and the validity-reliability research has been done by Çapa et al. (2005). This nine point likert scale has 24 items. This scale has been improved as three sub-factors and they are named as "Self-Efficacy towards Pre-service teacher Participation" including 8 items, "Self-Efficacy towards Teaching Strategies" including 8 items, and "Self-Efficacy towards Classroom Management" including 8 items.

\subsection{Data Collection Tools}

After the data obtained by using the scales have been processed on SPSS-21 packaged software, whether there are missing data and extreme values have been determined before structural equation modeling has been set up by LISREL packaged software. A scaling model has been established for self-efficacy and attitude. For branch, self-efficacy, and attitude, structural equation model has been established, too. When the multivariate normality presumption has been tested before we determine the method of parameter estimation, value belonging to the scaling model set up for self-efficacy is 1,278 , for attitude the value is 1,292 , and the values related to the structural equation model is 1,082 ; that is to say, they are higher than the critical value 1,00 . Therefore, because it cannot provide multivariate normality presumption according to Jöreskog (2002), Robust Maximum Likelihood (RML) estimation model has been used instead of Maximum Likelihood (ML) estimation model.

\section{Results}

\subsection{First Sub-Problem}

How is the scaling model of pedagogical formation program pre-service teachers related to the teacher self-efficacies?

The distribution belonging to conformity index values related to scaling model for teacher self-efficacies is seen in Table 2. 
Table 2. Conformity index values related to scaling model for teacher self-efficacies

\begin{tabular}{llllllll}
\hline Model & $\mathrm{SB} \chi^{2} /(\mathrm{df})$ & RMSEA & SRMR & GFI & AGFI & CFI & NNFI \\
\hline $\begin{array}{l}\text { Model-1 } \\
\text { (Self-Efficacies) }\end{array}$ & $316,34 / 249=1.27$ & 0.039 & 0.055 & 0.93 & 0.90 & 0.99 & 0.99 \\
\hline
\end{tabular}

When the conformity index values in Table 2 are examined, it is seen that CFI accords with NNFI perfectly. Nevertheless, when we look at the values of GFI and AGFI, it is seen they are in a good conformity $(0.90<$, Tabachnick \& Fidell, 2001). On the other hand, because there is not much difference between them, it is seen that they provide multivariate normality. Due to the fact that RMSEA and SRMR poor conformity indexes are under the 0.08 critical values, it is concluded that they have good conformity index (Sümer, 2000). It is seen that the model belonging to Teacher Self-Efficacy Scale is confirmed. Related to this scale, the scaling model based on two-level three-factor Robust ML is seen in Figure 1.

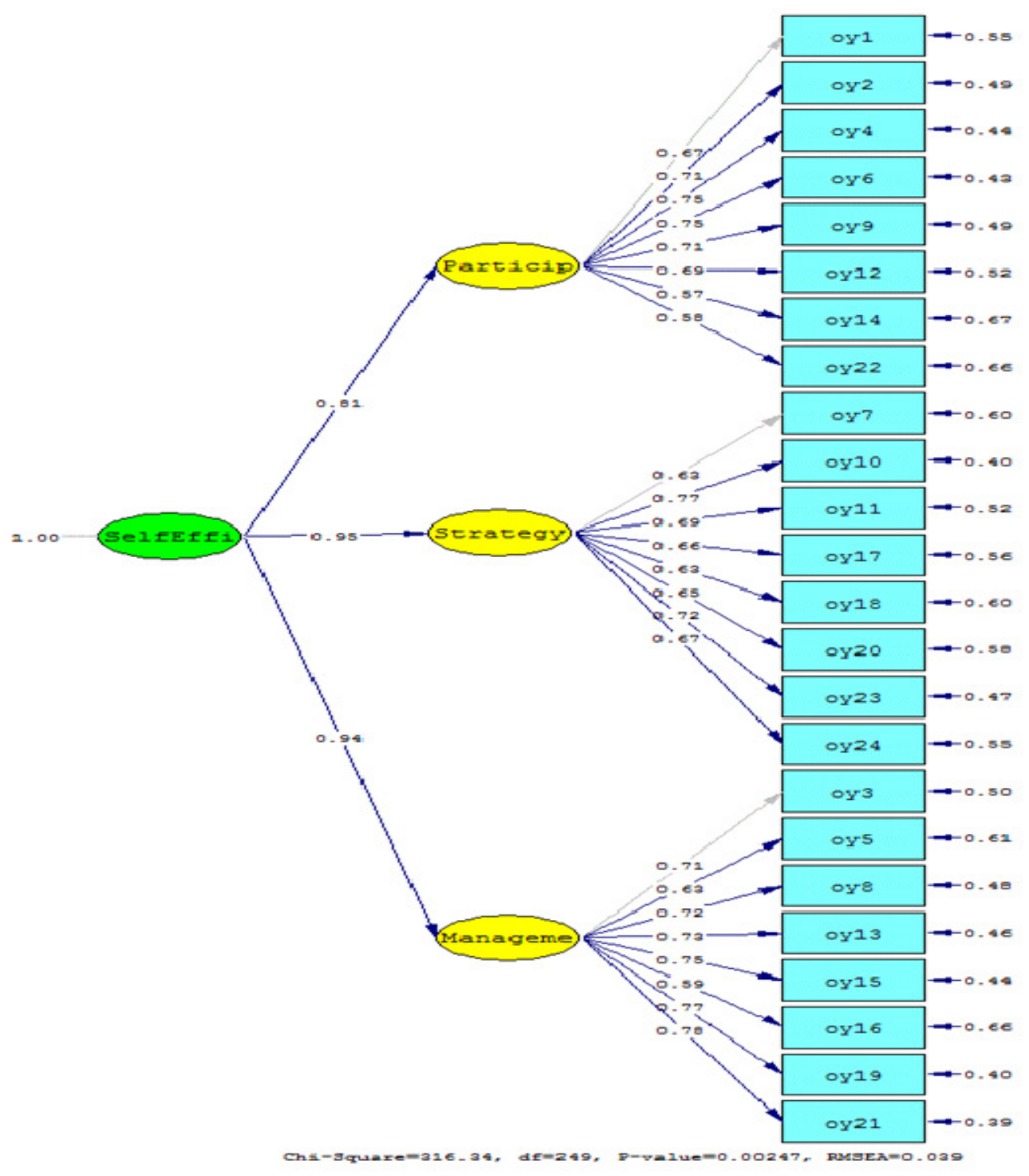

Figure 1. Two-level three-factor scaling model belonging to teacher self-efficacy scale 


\subsection{Second Sub-Problem}

How is the scaling model for pedagogical formation program pre-service teachers' attitude towards teaching profession?

The distribution related to the conformity index values incidental to scaling model for attitudes towards teaching profession is seen in Table 3.

Table 3. Conformity values belonging to scaling model for attitude scale towards teaching profession

\begin{tabular}{llllllll}
\hline Model & SB $\chi^{2} /(\mathrm{df})$ & RMSEA & SRMR & GFI & AGFI & CFI & NNFI \\
\hline Model-1 & $1719,84 / 431=3.99$ & 0.130 & 0.078 & 0.91 & 0.90 & 0.93 & 0.92 \\
(Attitude) & & & & & & & \\
\hline
\end{tabular}

When the conformity index values in Table 3 are examined, it is seen that CFI complies with NNFI acceptably. Likewise, GFI and AGFI show an acceptable conformity. It is also inferred that SRMR having 0.078 poor conformity index shows good conformity although RMSEA is above 0.08 critical value for poor conformity. In general, it can be said that this scaling model exhibits acceptable conformity and this scaling model related to Attitude Scale towards Teaching Profession is confirmed. The scaling model based on two-level three-factor Robust ML for Attitude Scale towards Teaching Profession is seen in Figure 2.

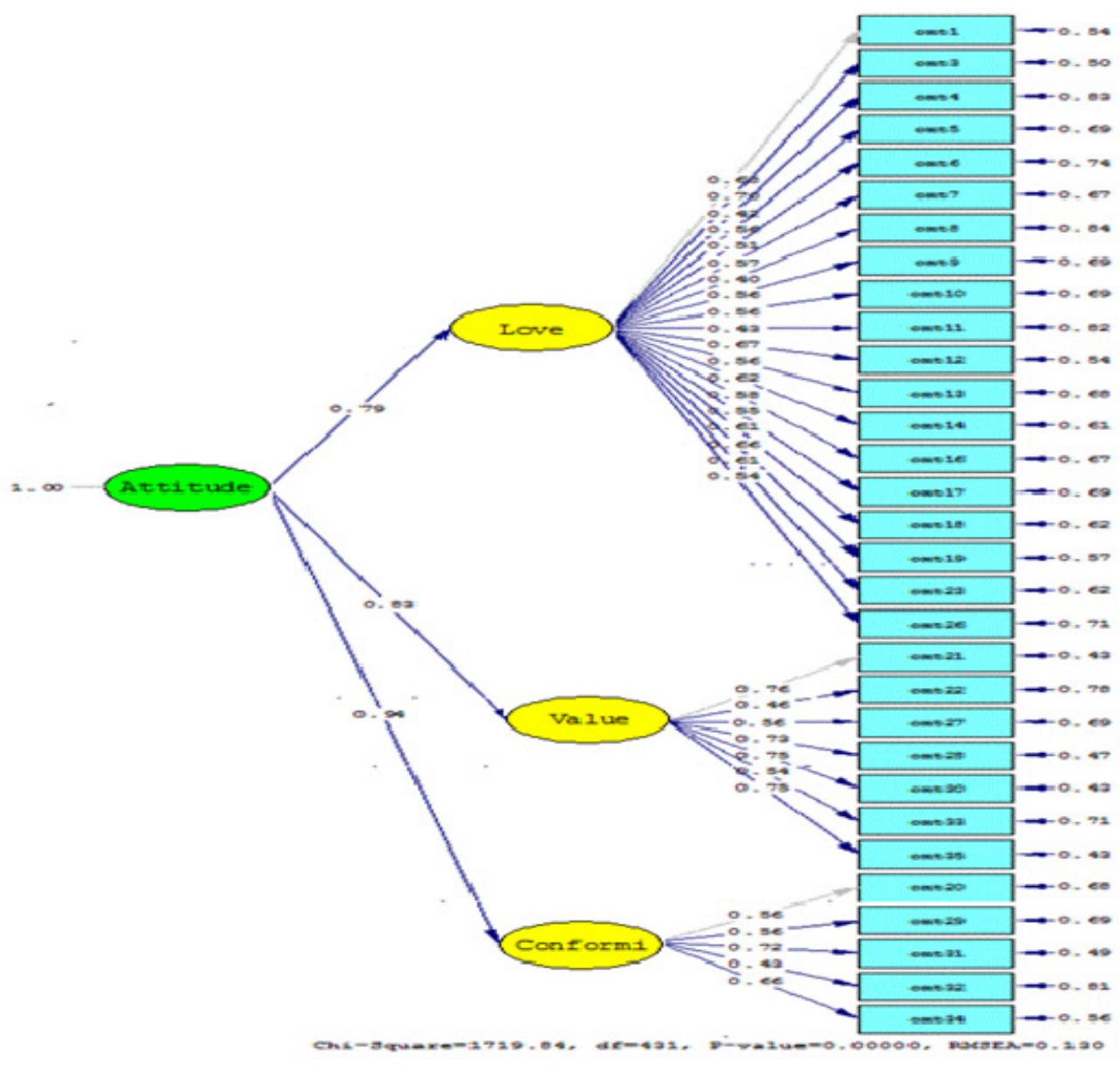

Figure 2. Scaling model based on two-level three-factor Robust ML for attitude scale towards teaching profession 


\subsection{Third Sub-Problem}

What are the effects of pedagogical formation program pre-service teachers' branches on teacher self-efficacies? And what are the effects of teacher self-efficacies on their attitudes towards teaching profession?

Conformity index values based on structural model related to the variables branches of pre-service teachers, self-efficacies of teachers and attitudes towards teaching profession are seen in Table 4.

Table 4. Conformity index values based on structural model related to the variables branches of pre-service teachers, self-efficacies of teachers and attitudes towards teaching profession

\begin{tabular}{llllllll}
\hline Model & $\mathrm{SB} \chi^{2} /(\mathrm{df})$ & RMSEA & SRMR & GFI & AGFI & CFI & NNFI \\
\hline Model-3 (Branch, Self-Efficacy, Attitude) & $21,35 / 13=1.64$ & 0.063 & 0.066 & 0.92 & 0.90 & 0.99 & 0.99 \\
\hline
\end{tabular}

When the conformity index values in Table 4 are examined, it is seen that CFI and NNFI show perfect conformity. Likewise, GFI and AGFI show an acceptable conformity. On the other hand, CFI and GFI provide multivariate normality because there is not too much difference between them. It is also inferred that SRMR having 0.078 poor conformity index shows good conformity although RMSEA is above 0.08 critical value for poor conformity. In general, it can be said that this scaling model exhibits acceptable conformity. The structural model related to the branches, self-efficacies and attitudes of pre-service teachers are seen in Figure 3.

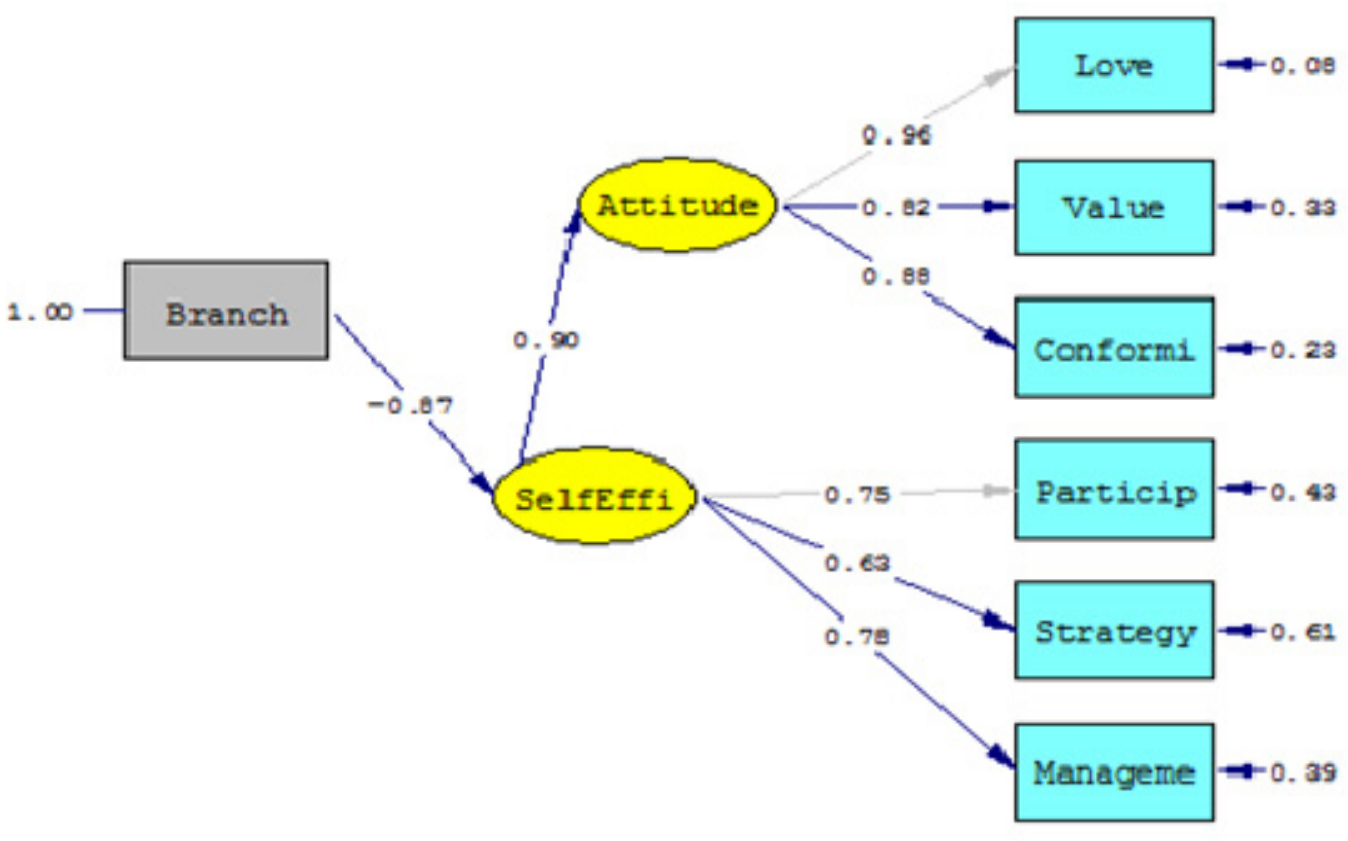

Chi-3quaxe=21.35, df=13, p-value=0.06635, RM9EA=0.063

Figure 3. Structural equation model related to pre-service teachers' branches, teacher self-efficacies and attitudes towards teaching profession

The interaction between variables belonging to the structural model in Figure 3 is stated in Table 5. Besides, how much of the scale is explained by sub-factors that create scales is seen in Table 5. 
Table 5. $\mathrm{R}^{2}$ Values related to structural equation model

\begin{tabular}{lc}
\hline Relationship Direction & $\mathrm{R}^{2}$ \\
\hline Branch $\rightarrow$ Teacher Self-Efficacies & 0.77 \\
Teacher Self-Efficacies $\rightarrow$ Attitude towards Teaching Profession & 0.81 \\
Branch $\rightarrow$ Attitude towards Teaching Profession & 0.62 \\
Attitude $\rightarrow$ Love & 0.92 \\
Attitude $\rightarrow$ Value & 0.67 \\
Attitude $\rightarrow$ Conformity & 0.77 \\
Self-Efficacy $\rightarrow$ Pre-service teacher Participation & 0.57 \\
Self-Efficacy $\rightarrow$ Teaching Strategy & 0.39 \\
Self-Efficacy $\rightarrow$ Classroom Management & 0.61 \\
\hline
\end{tabular}

By looking at Table 5, when the structural equation model related to the pedagogical formation program pre-service teachers' branches, teacher self-efficacies and attitudes towards teaching profession is examined, it is seen that the effect of graduation branches of pre-service teachers on teacher self-efficacies is $R^{2}=0,77$. As it is stated in the table, the effect of self-efficacies of pre-service teachers on attitude towards teaching profession is $\mathrm{R}^{2}=0,81$. The effect of the graduation branches of pre-service teachers on attitude towards teaching profession is $\mathrm{R}^{2}=0,62.92 \%$ of attitudes towards teaching profession is love, $67 \%$ of them is attitude towards value as a sub-factor, and $77 \%$ is explained as attitude towards conformity. $57 \%$ of efficacy levels incidental to teacher self-efficacies of pre-service teachers is about the self-efficacy related to pre-service teacher participation, and $61 \%$ of them is stated as self-efficacy related to classroom management.

\section{Discussion}

When the researchers evaluate the findings of this study and the research results in the literature, it can be clearly seen that there are similar and also different results about teacher efficacy in terms of branch. In some studies related to the findings of other researchers they state that there is no significant difference in the level of teacher efficacy when it comes to the branch as a variable of the study (Karahan \& Balat, 2011; Üstüner et al., 2009). On the other hand, in many studies, it has been found that there are some differences on the basis of levels of teachers' attitudes towards teaching strategies and professional competence in different branches (Altunçekiç, Yaman, \& Koray, 2005; Şeker, Deniz, \& Görgen, 2005). As for the self-efficacy and the attitudes of pre-service teachers, achievement and attitude are affected by teachers' self-efficacy positively and this provides teachers to show positive attitudes towards teaching profession (Tschannen-Moran, Hoy A., \& Hoy W., 1998).

Besides, when we look at the studies that have been done on self-efficacy, Denzine, Cooney and McKenzie, who describe self-efficacy as the teachers' beliefs about their own abilities in affecting pre-service teacher and learning process positively, have applied confirmatory factor analysis in the study that they have done with 387 pre-service teachers in order to investigate the validity of "Teacher Efficacy Scale" (2005, pp. 689-708).

Among 255 experienced and inexperienced teachers attending to the study, Tschannen-Moran and Woolfolk Hoy (2006, pp. 944-956) assert that contextual factors such as teaching resources and interpersonal support are more conspicuous in self-efficacy beliefs of inexperienced teachers while these contextual factors have less role in self-efficacy beliefs of experienced teachers. Another study towards the validity and reliability of the scales for teachers self-efficacy beliefs developed by Tschannen-Moran and Woolfolk Hoy and adapted to Turkish by Çapa et al. have been done with 628 pre-service teachers (2005, pp. 75-81).

By using this scale adapted to Turkish by Çapa et al., Eker (2014, pp. 162-178) has made a research on the self-efficacy belief levels of class teachers and he points self-efficacy values with three subtitles like self-efficacy towards pre-service teacher participation, self-efficacy towards teaching strategies, and self-efficacy towards classroom management.

In the study of Milner and Woolfolk-Hoy (2003), they have concluded that there is a significant difference in teacher self-efficacy in terms of branch and the branch variable has an affect creating difference on self-efficacy. 


\subsection{Conclusion}

When the results obtained from findings pertain to the structural equation model based on pre-service teachers' branches, self-efficacies, and attitudes are examined;

It is inferred that the scaling model based on teacher self-efficacies of pre-service teachers and the scaling model based on their attitudes towards teaching profession have acceptable conformity levels and these models are confirmed.

In this research, it is concluded that the established structural model belonging to pre-service teachers' graduated branches, their senses of teacher self-efficacy and their attitudes towards teaching profession has been confirmed and that conformity index values show acceptable consistence. In addition to this, it can also be arrived at the conclusion that variables determined for the structural model predict one another in a high-level; and therefore, declaration variances connected with the regression coefficient are high.

Graduation branches of pre-service teachers explain $77 \%$ of their self-efficacies. The change of pre-service teachers' graduation branch variables has great contribution to the increase of teacher self-efficacies; therefore, it is observed that the change between branches affects teacher self-efficacies. That is to say, branch variable has an important effect on training teachers having high self-efficacies.

Teacher self-efficacies of pre-service teachers explain $81 \%$ of attitudes towards teaching profession. It is concluded that formation pre-service teachers who have high-level self-efficacies will have great attitudes towards teaching profession. It is required to train individuals who have high-level self-efficacies in order to increase pre-service teachers' attitudes towards teaching profession.

Graduation branches of pre-service teachers explain $62 \%$ of attitudes towards teaching profession. It is observed that graduation branches of pre-service teachers affect the attitudes towards teaching profession above medium level.

It is seen that love is the most important factor related to the pre-service teachers' attitude towards teaching profession and the less important factor is value. The most important factor which affects the pre-service teachers' efficacies towards teacher self-efficacy is the self-efficacy based on classroom management and the less important factor is the self-efficacy based on teaching strategies.

\subsection{Recommendations}

When the teacher self-efficacies of pre-service teachers are examined, it is required that more productive activities should be done on the basis of theory and application related to the teaching strategies due to the fact that level of significance of teaching strategies is a little low. By looking at the examination of pre-service teachers' attitudes towards teaching profession, it is advised that the importance with respect to the emotional factors is given to the pre-service teachers by associating to occupational values by academicians giving formation training. During the formation training of pre-service teachers, teaching strategies should be planned by taking the graduation branches into consideration. Solutions to the inequality between graduation branches should be produced in order that teacher self-efficacies of pre-service teachers and their attitudes towards teaching profession show similar distributions.

\section{References}

Altunçekiç, A., Yaman, S., \& Koray, O. (2005). A study on self-efficacy belief levels and problem solving skills of teacher candidates (Kastamonu city case). Kastamonu Journal of Education, 13(1), 93-102.

Anderson, L. W. (1988). Attitude measurement: Attitudes and their measurement. In J. P. Keeves (Ed.), Educational research methodology and measurement: An international handbook (pp. 421-426). New York: Pergamon Press.

Bandura, A. (1977). Self-efficacy: Toward a unifying theory of behavioral change. Psychological Review, 84, 191-215. https://dx.doi.org/10.1037/0033-295X.84.2.191

Baykara-Pehlivan, K. (2004). Sınıf öğretmeni adaylarının öğretmenlik mesleğine yönelik tutumları ve okul tutumları arasındaki ilişki. Eğitim Araştırmaları, 14, 211-218.

Çapa, Y., Çakıroğlu, J., \& Sarıkaya, H. (2005). The development and validation of a Turkish version of teachers' sense of efficacy scale. Education and Science, 30(137), 74-81.

Çetin, Ş. (2003). Anadolu öğretmen lisesi ve düz lise çıkışl eğitim fakültesi öğrencilerinin öğretmenlik mesleğine yönelik tutumlarının karşılaştırlması (Doctoral Dissertation). Retrieved from http://tez.yok.gov.tr adresinden erişilmiştir 
Denzine, J. B., \& Cooney ve, R. M. (2005). Confirmatory factor analysis of the teacher efficacy scale for pre-serviceteachers. British Journal of Educational Psychology, 75(4), 689-708. https://dx.doi.org/10.1348/000709905X37253

Eker, C. (2014). Sınıf öğretmenlerinin öz-yeterlilik inanç düzeyleri üzerine bir araştırma. Uşak Üniversitesi Sosyal Bilimler Dergisi, 7(1), 162-176.

Erdem, E., \& Demirel, Ö. (2007). Teacher self-efficacy belief. Social Behavior and Personality, 35(5), 349-358. https://dx.doi.org/10.2224/sbp.2007.35.5.573

Erden, M. (1995). Öğretmen adaylarının öğretmenlik sertifikası derslerine yönelik tutumları. HÜ Eğitim Fakültesi Dergisi, 11, 99-105.

Fraenkel, J. R., \& Wallen, N. E. (2006). How to design and evaluate research in education. New York: McGraw-Hill.

Gökçe, E. (2000). 21. Yüzy1lın öğretmeni. Çağdaş Ĕ̆itim, 270, 21-26.

Jöreskog, K. G. (2002). Structural equation modeling with ordinal variables using LISREL. Retrieved from http://www.ssicentral.com/lisrel/techdocs/ordinal.pdf

Karahan, S., \& Balat, G. U. (2011). Analysis of self-efficacy and burnout levels of educators working in schools of special education. Pamukkale University, Education Faculty Journal, 29, 1-14.

Milner, H. R., \& Woolfolk Hoy, A. (2003). A case study of an African American teacher's self efficacy, stereo-type threat, and persistence. Teaching and Teacher Education, 19, 263-276. https://dx.doi.org/10.1016/S0742-051X(02)00099-9

Sümer, N. (2000). Yapısal eşitlik modelleri: Temel kavramlar ve örnek uygulamalar. Türk Psikoloji Yazıları, 3(6), 49-74.

Sürücü, A. (1997). Öğretmenlik formasyonu alan ögrencilerin ögrretmenlik mesleğine yönelik tutumları (Master's Thesis). Selçuk Üniversitesi, Eğitim Bilimleri Enstitüsü, Konya. Retrieved from https//acikerisim.selcuk.edu.tr/

Şeker, H., Deniz, S., \& Görgen, İ. (2005). Non-thesis master's degree teacher candidates' evaluation on teacher efficacy. Journal of Theory and Practice in Educational Administration, 42, 237-253.

Tabachnick, B. G., \& Fidell, L. S. (Ed.). (2001). Using multivariate statistics. Needham Heights, MA: Allyn \& Bacon.

Tschannen-Moran, M., \& Woolfolk Hoy, A. (2006). The differential antecedents of self-efficacy beliefs of novice and experienced teachers. Teaching and Teacher Education, 23, 944-956. https://dx.doi.org/10.1016/j.tate.2006.05.003

Tschannen-Moran, M., Hoy, A. W., \& Hoy, W. K. (1998). Teacher efficacy: Its meaning and measure. Review of Educational Research, 68(2), 202-248. https://dx.doi.org/10.3102/00346543068002202

Ülgen, G. (1995). Eğitim psikolojisi. Ankara: Bilim Yayınları.

Üstüner, M., Demirtaş, H., Cömert, M., \& Özer, N. (2009). Self efficacy perceptions of teachers of secondary school education. Mehmet Akif Ersoy University, Education Faculty Journal, 9(17), 1-16.

\section{Copyrights}

Copyright for this article is retained by the author(s), with first publication rights granted to the journal.

This is an open-access article distributed under the terms and conditions of the Creative Commons Attribution license (http://creativecommons.org/licenses/by/4.0/). 